\title{
Effect of Integrated Management of Bean Anthracnose (Colletotrichum lindemuthianum Sacc. and Magn.) Through Soil Solarization and Fungicide Applications on Epidemics of the Disease and Seed Health in Hararghe Highlands, Ethiopia
}

\author{
Amin Mohammed ${ }^{1 *}$, Amare Ayalew ${ }^{2}$ and Nugussie Dechassa ${ }^{2}$ \\ ${ }^{1}$ Department of Plant, Science and Horticulture, College of Agriculture and Veterinary Science, Ambo University, P.O.BOX 19, Ambo, Ethiopia \\ ${ }^{2}$ Haramaya Universitiy, College of Agriculture, School of Plant Science P. O. BOX 138, Dire Dawa, Ethiopia
}

\begin{abstract}
Bean anthracnose is an important disease affecting common bean (Phaseolus vulgaris L.) in Hararghe highlands which produces common bean in large areas. The study was undertaken to evaluate the effect of integrated management of bean anthracnose through soil solarization and fungicide applications on disease development and seed health of common bean variety Mexican-142. Field experiments were conducted at Haramaya University and Hirna research station in 2010 summer season. Soil solarization was integrated with mancozeb and carbendazim seed treatments, with foliar sprays of carbendazim at the rate of $0.5 \mathrm{~kg} / \mathrm{ha}$ at 10 and 20 days intervals. The experiment was arranged in $2 \times 3 \times 3$ split-split plot design with three replications. There was significant difference in the anthracnose incidence, severity, infected pods per plant, infected seeds and AUDPC among treatments. Combined effect of mancozeb seed treatment with carbendazim spray at 10 day intervals and carbendazim seed treatment and carbendazim spray at 10 day intervals have reduced severity by $46.5 \%$ and $41 \%$, respectively at Haramaya. Interactions of solarized soil with carbendazim foliar spray frequencies at 10 days interval reduced the number of infected pods per plant by $58 \%$ at Haramaya and $38.9 \%$ at Hirna. In the results concluded that, the integration of soil solarization, seed treatments and foliar spray were found to be effective in reducing bean anthracnose epidemics and seed infection
\end{abstract}

Keywords: Colletotrichum lindemuthianum; Disease severity; Seed treatment; Soil solarization

\section{Introduction}

Common bean (Phaseolus vulgaris L.) is the most important food grain legume across tropical regions. Its production has been estimated at 18.43 million metrictons, which represents $32.7 \%$ of total world food grain-legume production [1]. For many millions of households in the tropical regions, the crop is a source of food nutrients (proteins, minerals, fiber, and vitamins) and also a source of cash [2]. The highest production and area under beans in Africa is in the east and central Africa regions, where beans are mainly grown by resource poor farmers [3]. Economic significance of bean is quite considerable since it represents one of the major food and cash crops [4]. In Ethiopia, common bean is mainly grown in eastern, southern, south-western and the Rift Valley areas of the country [5].

Rust (Uromyces appendiculatus (Pers. Unger)), anthracnose (Colletotrichum lindemuthianum Sacc. and Magn.), common bacterial blight (Xanthomonas campestris pv. phaseoli (Smith) Dawson are the major diseases identified to cause yield reduction in Ethiopia [6]. Among these major diseases, anthracnose caused by $C$. lindemuthianum is the most devastating seed-borne disease of common bean [7]. Infested debris and soils are among the potential sources of primary inoculum. According to Pastor-Corrales and $\mathrm{Tu}$ [8], C. lindemuthianum can survive two to five years on dry infected plant materials left in the field under natural conditions. This disease is widespread in nearly all bean growing regions of the world and often causes severe damage, which affects yield, seed quality, and marketability [7].

Significant disease development and yield losses occur if weather conditions are prolonged throughout the pod formation and pod filling stages of the crop [9]. The management of primary inoculum sources is key strategy in controlling bean anthracnose [10]. Various control strategies have been advocated in an attempt to reduce losses caused by anthracnose [11]. The use of seed treatment is an important practice for disease control in general and for anthracnose management in particular [12]. However, seed treatment alone could be inefficient and would often require follow-up applications of contact or systemic foliar fungicides [13].

Soil solarization has been identified as an environmentally sound, pesticide free, low cost method of controlling a wide variety of soilborne fungal plant pathogens, parasitic nematodes and weeds [14]. Minimizing seed infections and destruction of soil-borne inoculum could lead to effective management of the disease in the growing crop and seed. In spite of such treatments, should the disease appear during the season, it can be handled through foliar application of suitable fungicides. However, there is no empirical research data locally on integrated disease management addressing both seed and soil-borne inoculum sources of bean anthracnose. Therefore, the present study was undertaken to evaluate the effect of integrated management of

*Corresponding author: Amin Mohammed, Ambo University, College of Agriculture and Veterinary Science, Department of Plant, Science and Horticulture, P.O.BOX 19, Ambo, Ethiopia, E-mail: aminmahammed@gmail.com

Received May 23, 2013; Accepted June 19, 2013; Published June 23, 2013

Citation: Mohammed A, Ayalew A, Dechassa N (2013) Effect of Integrated Management of Bean Anthracnose (Colletotrichum lindemuthianum Sacc. and Magn.) Through Soil Solarization and Fungicide Applications on Epidemics of the Disease and Seed Health in Hararghe Highlands, Ethiopia. J Plant Pathol Microb 4: 182 doi:10.4172/2157-7471.1000182

Copyright: (c) 2013 Mohammed A, et al. This is an open-access article distributed under the terms of the Creative Commons Attribution License, which permits unrestricted use, distribution, and reproduction in any medium, provided the original author and source are credited. 
Citation: Mohammed A, Ayalew A, Dechassa N (2013) Effect of Integrated Management of Bean Anthracnose (Colletotrichum lindemuthianum Sacc. and Magn.) Through Soil Solarization and Fungicide Applications on Epidemics of the Disease and Seed Health in Hararghe Highlands, Ethiopia. J Plant Pathol Microb 4: 182 doi:10.4172/2157-7471.1000182

bean anthracnose through soil solarization and fungicide applications on epidemics of the disease and seed health

\section{Materials and Methods}

\section{Description of the study sites}

The study was conducted at Haramaya University experimental field and Hirna research Station. Haramaya is located at $9^{\circ} 26^{\prime} \mathrm{N}$ latitude, $42^{\circ} 30^{\prime} \mathrm{E}$ longitude and at an altitude of 1980 meters above sea level. The site received mean annual rainfall of $780 \mathrm{~mm}$, with mean minimum and maximum temperatures of $8.25^{\circ} \mathrm{C}$ and $24.4^{\circ} \mathrm{C}$, respectively. On the other hand, Hirna is located at $9^{\circ} 12^{\prime} \mathrm{N}$ latitude, $41^{\circ} 4^{\prime} \mathrm{E}$ longitude and at an altitude of 1870 meter above sea level. The site received a mean annual rainfall of $990-1010 \mathrm{~mm}$ with an average temperature of $24^{\circ} \mathrm{C}$.

\section{Experimental materials and design}

The bean variety Mexican-142, which is susceptible to anthracnose [15], was used for both experiments; in addition, mancozeb was used for seed treatment at $3 \mathrm{~g} / \mathrm{kg}$ while carbendazim was used for seed treatment at $2 \mathrm{~g} / \mathrm{kg}$ and as foliar spray at $0.5 \mathrm{~kg} / \mathrm{ha}$. Transparent plastic sheet was used for soil treatment (Table 1).

Two soil solarization treatments by comparing them with control were evaluated. After ploughing the plots, the area to be solarized was leveled and made free from weeds, debris, and large clods that could raise the plastic-off ground. The soil was turned over by hand and raked smooth to provide an even surface. Transparent plastic sheeting that was 0.001 inch thick was laid by hand (i.e. close to the soil), and anchored to the soil by burying the edges in trench around the treated area. The plastic was kept in place from $4^{\text {th }}$ week of May to $4^{\text {th }}$ week of June in 2010 for one month to allow the soil to heat to the greatest depth as possible.

Foliar spray with carbendazim (Bavistin DF) at the rate of $0.5 \mathrm{~kg} \mathrm{ha}^{-1}$ [16], and at three rounds of application (including control) was used as the third component of the experimental treatments. Frequencies consisted of spraying at 10 days' interval as of disease onset, spraying at 20 days' interval and no spray (Table 1). Spraying of fungicide started 42 days after sowing (DAS) at Haramaya and 50 DAS at Hirna, i.e., when the first symptom of the disease appeared. The experiments relied entirely on natural infection, because both sites are hot spot areas for the disease. Seeds were treated with mancozeb or carbendazim 24 hours before sowing and untreated seeds served as control. Planting was done on July 5, 2010 at Haramaya University and July 13, 2010 at Hirna research Station on previous plots plated with common bean to get increased disease pressure.

The treatments consisted of two soil solarization (solarized and non solarized), three foliar spray frequencies (no spray, 10 days interval, 20

\begin{tabular}{|c|c|c|c|}
\hline \multicolumn{2}{|c|}{ Fungicides } & \multirow[t]{2}{*}{ Dosage* } & \multirow{2}{*}{$\begin{array}{l}\text { Seed treatment and spray } \\
\text { frequencies }\end{array}$} \\
\hline Trade name & Common name & & \\
\hline Pencozeb 80 WP & Mancozeb & $3 \mathrm{~g} / \mathrm{Kg}$ seeds & $\begin{array}{l}\text { Seed treatment } 24 \text { hour } \\
\text { before sowing }\end{array}$ \\
\hline \multirow[t]{3}{*}{ Bavistin DF } & \multirow[t]{3}{*}{ Carbendazim } & $2 \mathrm{~g} / \mathrm{Kg}$ seeds & $\begin{array}{l}\text { Seed treatment } 24 \text { hour } \\
\text { before sowing }\end{array}$ \\
\hline & & \multirow[t]{2}{*}{$(0.5 \mathrm{Kg} / \mathrm{ha})$} & $\begin{array}{l}\text { Every } 10 \text { days ( } 3 \text { sprays both } \\
\text { at Haramaya and Hirna) }\end{array}$ \\
\hline & & & $\begin{array}{l}\text { Every } 20 \text { days ( } 2 \text { sprays both } \\
\text { at Haramaya and Hirna) }\end{array}$ \\
\hline
\end{tabular}

*Seed treatment dosages used were based on recommendation of the manufacturers and dosage used for foliar spray was based on CIAT [16].

Table 1: List of fungicides, their respective dosage and spray frequencies. days interval) and three fungicide treatments (mancozeb, carbendazim and no treatment) combined factorially in a split-split plot design with three replications at each of the experimental site. Total of 18 treatment combinations were evaluated. Main plots were assigned to soil solarization, sub-plots to frequencies of foliar sprays and sub-sub plots to seed treatments. Each sub-sub-plot $(2.4 \times 2)$ consisted of six rows, and distance between rows and between plants were 40 and 10 $\mathrm{cm}$, respectively. There were 20 plants per row and the four central rows were harvested for determining yield. There were $0.8 \mathrm{~m}$ space between sub-sub plots, $1 \mathrm{~m}$ between sub-plots and $1 \mathrm{~m}$ between main plots. Planting was done on July 5, 2010 at Haramaya and July 13, 2010 at Hirna on previous plots sown of common bean to get increased disease pressure; the disease was found previously in the experimental plots used.

\section{Data collection and analysis}

Anthracnose incidence and severity assessments were started at disease onset, 10 days' intervals at both locations. Using ten randomly pre-tagged bean plants in the four central rows, severity was rated using standard disease scales of 1- 9 [17], where, $1=$ no visible disease symptoms and $9=$ more than $25 \%$ of leaf surface area with large coalescing and generally necrotic lesions resulting in defoliation. The severity grades were converted into percentage severity index (PSI) for analysis [18].

\section{$P S I=\frac{\text { Sum of numerical ratings } \times 100}{\text { No.of plants scored } \times \text { maximum score on scale }}$}

Number of infected pods per plant was determined as the average number of infected pods of ten randomly pre-tagged plants.

\section{Seed health testing}

Direct (visual) inspection to observe signs of the pathogen and agar plate incubation methods were used for seed health testing. For visual inspection method, 100 seeds were taken at random from harvested seed lots of each sub-sub plot and examined for brown discoloration visually and under stereomicroscope, and finally percentages of seeds infected by Colletotrichum lindemuthianum were recorded. For agar plate incubation, 100 seeds per sample were selected, dipped in $1 \%$ sodium hypochlorite solution and rinsed three times in sterilized distilled water. Then seeds were transferred to PDA plates ( 5 seeds per plate) and incubated at $25^{\circ} \mathrm{C}$ for 10 days. The numbers of infected seeds were determined and at the end percentages of total infection by anthracnose were calculated [19]. The area under the diseases progress curve (AUDPC) from PSI was computed using the following formula [20]:

$$
\operatorname{AUDPC}=\sum_{\mathrm{i}=1}^{\mathrm{n}-1}(0.5(\mathrm{xi}+1+\mathrm{xi})(\mathrm{ti}+1-\mathrm{ti}))
$$

Where $\mathrm{n}$ is total number of assessment times, ti is time of the $\mathrm{i}^{\text {th }}$ assessment in days from the first assessment date, $x i$ is percentage of disease severity at $\mathrm{i}^{\text {th }}$ assessment. Since the epidemic periods of the two locations varied, AUDPC were standardized by dividing the values to the epidemic period of the respective locations [20], which were 40 and 30 days at Haramaya and Hirna, respectively.

All data were subjected to analysis of variance using General Linear Model (GLM) procedure of SAS statistical version 9.2 software [21] except mean separation for significant interaction effects which was carried out using GenStat version 12.1 software [22]. Least Significant Difference (LSD) was used to separate means. 
Citation: Mohammed A, Ayalew A, Dechassa N (2013) Effect of Integrated Management of Bean Anthracnose (Colletotrichum lindemuthianum Sacc. and Magn.) Through Soil Solarization and Fungicide Applications on Epidemics of the Disease and Seed Health in Hararghe Highlands, Ethiopia. J Plant Pathol Microb 4: 182 doi:10.4172/2157-7471.1000182

\section{Results and Discussion}

\section{Incidence of anthracnose}

Incidence of bean anthracnose showed significant difference between solarized and non-solarized plots at 52 days after sowing (DAS) $(P<0.05)$ and highly significant difference at 62, 72, 82 and 92 DAS $(P<0.01)$ at Haramaya and all four successive disease assessments at Hirna $(P<0.01)$. At final date (92 and 90 DAS) of disease assessment at Haramaya and Hirna, incidence reached $72.1 \%$ and $50.7 \%$, respectively in non-solarized soil, $60.7 \%$ and $45.6 \%$ in solarized soil. In these experiments, disease incidence in solarized soil decreased when compared with non-solarized soil. The experimental field had also been planted to bean in the previous year. Hence, there were considerable amounts of initial inoculum bean crop residue in the field. As reported by Dillard and Cobb [23], in areas where beans are consecutively cropped, over seasonal inoculum can initiate epidemics of bean anthracnose. The primary inoculum from infested debris was relatively more damaging than other inoculum sources, causing early epidemic development and yield reduction [24].

The effect of seed treatments on the incidence of anthracnose was highly significant $(P<0.01)$ difference at 52, 62 DAS at Haramaya, 60 DAS at Hirna, and showed significant difference $(P<0.05) 72$ DAS at Haramaya, 70, 80 and 90 DAS at Hirna. At Hirna, the maximum incidence was recorded from control (53.9\%), while lower levels of incidence were encountered for seed treatments with mancozeb and carbendazim, $43.3 \%$ and $47.2 \%$, respectively at final date of incidence assessment (Table 2).

There was no significant variation in disease incidence between frequencies of carbendazim foliar sprays at $62,72,82$ and 92 DAS dates of disease assessment at Haramaya except initial date 52 DAS $(P<0.01)$, while significant differences were observed at all dates of assessment at Hirna $(P<0.01)$. Lower mean incidence was calculated from carbendazim foliar sprays at $10(16.1 \%)$ and $20(17.2 \%)$ days' intervals at initial date of incidence assessment 60 DAS, while the control

\begin{tabular}{|l|l|l|l|l|}
\hline Treatments & \multicolumn{3}{l}{$\begin{array}{l}\text { Disease incidence at } \\
\text { Haramaya DAS (\%) }\end{array}$} & $\begin{array}{l}\text { Disease incidence at Hirna } \\
\text { DAS (\%) }\end{array}$ \\
\cline { 2 - 4 } & Initial (52) & Final (92) & Initial (60) & Final (90) \\
\hline Soil solarization & 19.6 & 60.7 & 15.9 & 45.6 \\
\hline Solarized & 24.4 & 72.1 & 21.5 & 50.7 \\
\hline Non-solarized & 9.1 & 2.6 & 7.3 & 1.9 \\
\hline CV (\%) & 3.6 & 6.5 & 3.1 & 3.7 \\
\hline LSD (5\%) & & & & \\
\hline Foliar spray & 18.9 & 63.9 & 16.1 & 45.6 \\
\hline CFS10 & 19.4 & 66.1 & 17.2 & 47.2 \\
\hline CFS20 & 27.8 & 72.2 & 22.8 & 51.7 \\
\hline Control & 35.9 & 13.0 & 36.1 & 12.4 \\
\hline CV (\%) & 4.4 & 7.9 & 3.8 & 4.4 \\
\hline LSD (5\%) & & & & \\
\hline Seed treatment & 18.9 & 63.3 & 15.6 & 43.3 \\
\hline MST & 22.8 & 66.7 & 17.8 & 47.2 \\
\hline CST & 24.4 & 72.2 & 22.8 & 53.9 \\
\hline Control & 24.2 & 13.4 & 31.8 & 15.8 \\
\hline CV (\%) & 4.5 & 7.9 & 3.8 & 4.5 \\
\hline LSD (5\%) & & & \\
\hline
\end{tabular}

MST=Mancozeb seed treatment; CST=Carbendazim seed treatment; CFS10 and DAS=Days after sowing; $20=$ Carbendazim foliar spray at 10 and 20 days interval; LSD=Least significant difference.

Table 2: Effect of soil solarization, seed treatment and foliar sprays on incidence of common bean anthracnose at Haramaya and Hirna during 2010 main cropping season. showed higher incidence (22.8\%) at Hirna. Similarly, $45.6 \%$ and $47.2 \%$ incidence was obtained at 10 and 20 days spray intervals, respectively whereas, the control showed $51.7 \%$ incidence at final date of assessment (90 DAS) at Hirna (Table 2). Notable differences in disease incidence were observed between Haramaya and Hirna. This might be due to high relative humidity, and frequent rain fall and low temperature were observed at Haramaya as compared to Hirna site during the 2010 main cropping season. As suggested by Tu [34], infection by $C$. lindemuthianum is favored by moderate temperatures between 13 and $26^{\circ} \mathrm{C}$ within an optimum of $17-24^{\circ} \mathrm{C}$. Infection and developments of the pathogen is delayed or prevented by temperature outside the range of $7-33^{\circ} \mathrm{C}$. Humidity of more than $92 \%$ or free moisture is required during all stages of conidium germination, incubation and subsequent sporulation.

This result agrees with Pastor-Corrales and Tu [8], who reported that preventive spraying of foliage at flower initiation, late flowering and pod-filling with protective and systemic fungicides like maneb, zineb, benomyl, carbendazim, and fentin hydroxide have been used to control bean anthracnose. As reported by Sindhan and Bose [25], carbendazim was effective as seed dressing and foliar sprays, and these treatments increase seed germination and seed yield, while reducing disease incidence. Study conducted by [26] support present experiment in that sorghum anthracnose can best be managed on the early susceptible variety by integrating seed dressing treatment supplemented with foliar sprays.

\section{Severity of anthracnose}

Percent severity index (PSI) calculated from disease severity assessed five times at Haramaya and four times at Hirna was significantly affected by soil solarization at all dates of severity assessment. Percent severity index was higher in non-solarized soil as compared to solarized soil at both locations (Table 3).

There were significant interaction effects $(P<0.01)$ between levels of soil solarization and seed treatment in reducing PSI at 52, 6272 DAS at Haramaya and non significant difference at 82, 92 DAS at Haramaya and all dates of severity assessment at Hirna (Table 3). There were significant interaction effects between soil solarization $\mathrm{x}$ foliar sprays $(P<0.01)$ at 52, 62 and 92 DAS at Haramaya and $(P<0.05) 70,80$ and 90 DAS at Hirna. Percentage severity index was not significantly different at the remaining dates of severity assessment at both locations. The combination of solarized soil with carbendazim sprays at 10 and 20 days intervals reduced PSI by $16.9 \%$ and $15.9 \%$, respectively over the control (non-solarized, no spraying) at the final day at Haramaya. On the other hand, the combination of non-solarized soil with carbendazim sprays at 10 and 20 days intervals reduced PSI by $8.8 \%$ and $7 \%$, respectively over the control at initial date of severity assessment (Table 3 ). At Hirna during final severity assessment, the interactions of 10 and 20 days intervals spray frequencies of carbendazim with non-solarized soil showed lower PSI of $25.2 \%$ and $31.8 \%$, respectively than the control $(35.8 \%)$ (Table 3). Soil solarization alone or with low dosages of a fungicide, biocide and bio-agent resulted in complete reduction of the pathogen; soil solarization integrated with applications of T. harzianum, carbendazim and neem was the most effective treatment [27]. There were significant interaction effects between seed treatment $\times$ foliar sprays in reducing PSI $(P<0.01)$ at Haramaya which were non significant at all dates of severity assessment at Hirna. The combination of mancozeb seed treatment with spray frequencies of carbendazim at 10 and 20 day intervals showed PSI $28.2 \%$ and $29.3 \%$, respectively over the control $(52.7 \%)$ at final date of disease assessment at Haramaya. Likewise, the interaction of carbendazim seed treatment with carbendazim spray at 
Citation: Mohammed A, Ayalew A, Dechassa N (2013) Effect of Integrated Management of Bean Anthracnose (Colletotrichum lindemuthianum Sacc. and Magn.) Through Soil Solarization and Fungicide Applications on Epidemics of the Disease and Seed Health in Hararghe Highlands, Ethiopia. J Plant Pathol Microb 4: 182 doi:10.4172/2157-7471.1000182

\begin{tabular}{|c|c|c|c|c|c|}
\hline \multicolumn{2}{|c|}{ Treatments interaction } & \multicolumn{2}{|c|}{$\begin{array}{l}\text { PSI at Haramaya } \\
\text { DAS (\%) }\end{array}$} & \multicolumn{2}{|c|}{ PSI at Hirna DAS (\%) } \\
\hline & & Initial (52) & Final (92) & Initial (60) & Final (90) \\
\hline $\begin{array}{c}\text { Soil } \\
\text { solarization }\end{array}$ & $\begin{array}{l}\text { Seed } \\
\text { treatment }\end{array}$ & & & & \\
\hline \multirow[t]{3}{*}{ Solarized } & MST & 13.8 & 28.7 & 16.3 & 25.2 \\
\hline & CST & 13.1 & 29.1 & 16.6 & 25.7 \\
\hline & US & 20.7 & 38.5 & 15.6 & 26.2 \\
\hline \multirow[t]{2}{*}{ Non-solarized } & MST & 13.9 & 33.1 & 20.3 & 29.4 \\
\hline & CST & 14.3 & 34.8 & 20.9 & 31.4 \\
\hline \multicolumn{2}{|c|}{ US } & 26.9 & 44.7 & 21.9 & 32.1 \\
\hline \multicolumn{2}{|c|}{ CV (\%) } & 13.0 & 12.3 & 9.6 & 9.7 \\
\hline \multicolumn{2}{|c|}{ LSD at $5 \%$ for $\mathrm{SS} \times \mathrm{ST}$} & 4.4 & NS & NS & NS \\
\hline Soil solarization & Foliar spray & & & & \\
\hline \multirow[t]{3}{*}{ Solarized } & CFS10 & 13.3 & 30.5 & 19.0 & 21.9 \\
\hline & CFS20 & 15.1 & 31.5 & 15.1 & 25.2 \\
\hline & UF & 19.3 & 34.4 & 14.3 & 29.9 \\
\hline \multirow[t]{2}{*}{ Non-solarized } & CFS10 & 15.1 & 32.6 & 21.2 & 25.2 \\
\hline & CFS20 & 17.9 & 32.7 & 17.5 & 31.8 \\
\hline \multicolumn{2}{|c|}{ UF } & 22.1 & 47.4 & 24.4 & 35.8 \\
\hline \multicolumn{2}{|c|}{ CV $(\%)$} & 14.7 & 12.1 & 25.8 & 21.1 \\
\hline \multicolumn{2}{|c|}{ LSD at $5 \%$ for $S S \times F S$} & 2.5 & 4.3 & NS & 14 \\
\hline Seed treatment & Foliar spray & & & & \\
\hline \multirow[t]{3}{*}{ MST } & CFS10 & 12.2 & 28.2 & 20.0 & 29.6 \\
\hline & CFS20 & 13.4 & 29.3 & 16.3 & 24.8 \\
\hline & UF & 15.9 & 35.3 & 18.5 & 27.4 \\
\hline \multirow[t]{3}{*}{ CST } & CFS10 & 14.5 & 31.1 & 21.1 & 31.8 \\
\hline & CFS20 & 13.6 & 30.3 & 15.9 & 25.2 \\
\hline & UF & 12.9 & 34.6 & 19.2 & 28.5 \\
\hline \multirow[t]{3}{*}{ US } & CFS10 & 15.8 & 35.4 & 19.3 & 31.1 \\
\hline & CFS20 & 19.8 & 36.7 & 16.7 & 25.6 \\
\hline & UF & 33.2 & 52.8 & 20.4 & 30.7 \\
\hline \multicolumn{2}{|c|}{ CV (\%) } & 13.0 & 12.3 & 9.6 & 9.7 \\
\hline \multicolumn{2}{|c|}{ LSD at $5 \%$ for ST $\times$ FS } & 3.6 & 5.3 & NS & NS \\
\hline
\end{tabular}

MST=Mancozeb seed treatment; CST=Carbendazim seed treatment; CFS10 and $20=$ Carbendazim foliar spray at 10 and 20 days interval; UF=Unsprayed foliar; DAS =Days after sowing; US=Untreated seed; LSD=Least significant difference; FS=Foliar spray; ST=Seed treatment; SS=Soil solarization; NS=Non significant difference

Table 3: Effect of soil solarization $x$ seed treatment, soil solarization $x$ foliar sprays and seed treatment $x$ foliar sprays interactions on percentage severity index (PSI) of anthracnose at Haramaya and Hirna during 2010 main cropping season.

intervals of 10 and 20 days showed PSI of $31.1 \%$ and $30.3 \%$, respectively on the final date of severity assessment at Haramaya (Table 3).

Carbendazim foliar spray at 10 and 20 day intervals alone showed PSI levels of $35.4 \%$ and $36.7 \%$, respectively at Haramaya during final severity assessment. Jenny [28] reported that the seed treatment alone provide effective control for a maximum of four to six weeks after sowing, but do not provide absolute control. This study also showed that combination of seed treatment with foliar spray was more effective in reducing severity than seed treatment or foliar applications of fungicides alone.

There were significant interaction effects among soil solarization $\mathrm{x}$ seed treatment $\mathrm{x}$ foliar sprays $(P<0.01)$ at 52,72 and 82 DAS at Haramaya and non significant at the remaining dates at Haramaya and all dates disease assessment at Hirna. The interactions of solarized soil $\mathrm{x}$ mancozeb seed treatment $\mathrm{x}$ carbendazim foliar sprays at 10 and 20 days gaps reduced PSI at initial date of anthracnose disease assessment. Similarly, the interaction of carbendazim seed treatment with the same fungicide foliar sprays frequencies at 10 and 20 days intervals reduced disease severity at initial (52 DAS) date of severity assessment.

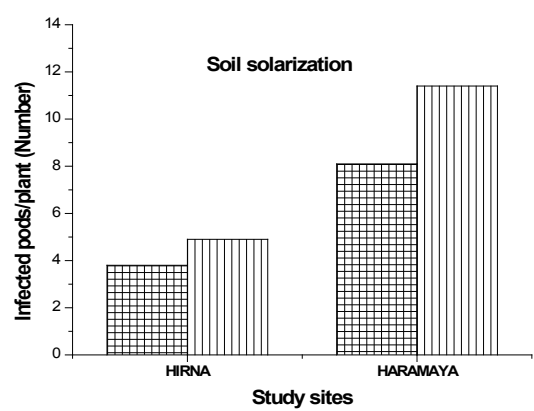

巴 Solarized

एسणा Non solarized

Figure 1: Infected pods per plant as affected by soil solarization at Haramaya and Hirna during 2010 main cropping season.

\begin{tabular}{|c|c|c|c|}
\hline \multicolumn{2}{|c|}{ Treatments interaction } & \multicolumn{2}{|c|}{ Infected pods/plant (Number) } \\
\hline & & \multirow[t]{2}{*}{ Haramaya } & \multirow[t]{2}{*}{ Hirna } \\
\hline Soil solarization & Foliar spray & & \\
\hline \multirow[t]{3}{*}{ Solarized } & CFS10 & 6.7 & 3.6 \\
\hline & CFS20 & 7.8 & 3.9 \\
\hline & UF & 9.8 & 3.8 \\
\hline \multirow[t]{2}{*}{ Non-solarized } & CFS10 & 7.9 & 3.9 \\
\hline & CFS20 & 9.9 & 5.0 \\
\hline \multicolumn{2}{|c|}{ UF } & 16.3 & 5.9 \\
\hline \multicolumn{2}{|c|}{$\mathrm{CV}(\%)$} & 18.2 & 18.0 \\
\hline \multicolumn{2}{|c|}{ LSD at $5 \%$ for $S S \times F S$} & 1.81 & 0.81 \\
\hline
\end{tabular}

CFS 10 and $20=$ Carbendazim foliar spray at 10 and 20 days interval; $U F=U n s p r a y e d$ foliar; LSD=Least significant difference; No=Number; FS=Foliar spray; SS=Soi solarization

Table 4: Effect of soil solarization $x$ foliar sprays interaction on infected pods per plant at Haramaya and Hirna during 2010 main cropping season.

The primary inoculum from infested debris was relatively more damaging, causing early epidemic development and yield reduction, and the difference among severity levels could be influenced by concentration of inoculum harbored which survived the temperature, relative humidity, and rain during over seasoning and the location of debris could have an effect [24]. Under favorable temperature and relative humidity, the pathogen leads to reduction of the grain quality due to occurrence of the tags, besides to decrease in the productive potential of the common bean [29]. Generally, variation in severity between locations might have been due to the differences in environmental factors, inoculum load and time of infection. At both study areas, the magnitude of disease severity was significantly different between levels of solarization, it was higher for non-solarized than solarized soil.

\section{Pod infection due to anthracnose}

Infected pods per plant varied significantly $(P<0.01)$ between the levels of soil solarization both at Haramaya and Hirna. At Haramaya, non-solarized soil held recorded higher number of infected pods per plant (11.4), compared with the solarized soil (8.1). Similarly at Hirna, lower infected pods per plant were recorded from solarized soil (3.4) than non-solarized soil (4.9) (Figure 1). There were significant interaction effects among the levels of soil solarization $\mathrm{x}$ foliar sprays on infected pods per plant at both locations. At Haramaya, the combination of non-solarized soil with carbendazim spray frequencies at 10 and 20 day intervals showed lower infected pods per plant of 7.9 and 9.9, respectively over the control (16.3).

Similarly, the combination of solarized soil with carbendazim spray frequencies at 10 and 20 days interval showed infected pods per plant of 
Citation: Mohammed A, Ayalew A, Dechassa N (2013) Effect of Integrated Management of Bean Anthracnose (Colletotrichum lindemuthianum Sacc. and Magn.) Through Soil Solarization and Fungicide Applications on Epidemics of the Disease and Seed Health in Hararghe Highlands, Ethiopia. J Plant Pathol Microb 4: 182 doi:10.4172/2157-7471.1000182

\begin{tabular}{|c|c|c|c|c|c|}
\hline \multicolumn{2}{|c|}{ Treatments interaction } & \multicolumn{2}{|c|}{ AUDPC (\%-days) } & \multicolumn{2}{|c|}{$\begin{array}{l}\text { Disease progress } \\
\text { rate (Units/day) }\end{array}$} \\
\hline & & Haramaya & Hirna & Haramaya & Hirna \\
\hline Soil solarization & Seed treatment & & & & \\
\hline \multirow[t]{3}{*}{ Solarized } & MST & 21.1 & 21.2 & 0.042 & 0.053 \\
\hline & CST & 20.8 & 20.7 & 0.095 & 0.051 \\
\hline & US & 29.1 & 30.1 & 0.085 & 0.037 \\
\hline \multirow[t]{2}{*}{ Non-solarized } & MST & 24.3 & 24.3 & 0.065 & 0.038 \\
\hline & CST & 24.7 & 24.7 & 0.097 & 0.041 \\
\hline \multicolumn{2}{|c|}{ US } & 36.6 & 36.7 & 0.098 & 0.061 \\
\hline \multicolumn{2}{|c|}{ CV (\%) } & 8.1 & 7.1 & 23.7 & 29.2 \\
\hline \multicolumn{2}{|c|}{ LSD at $5 \%$ for $\mathrm{SS} \times \mathrm{ST}$} & 2.4 & NS & 0.024 & NS \\
\hline Soil solarization & Foliar spray & & & & \\
\hline \multirow[t]{3}{*}{ Solarized } & CFS10 & 21.9 & 24.8 & 0.071 & 0.049 \\
\hline & CFS20 & 21.8 & 19.8 & 0.079 & 0.061 \\
\hline & UF & 27.3 & 18.3 & 0.078 & 0.033 \\
\hline \multirow[t]{2}{*}{ Non-solarized } & CFS10 & 25.3 & 22.5 & 0.088 & 0.042 \\
\hline & CFS20 & 26.4 & 22.2 & 0.070 & 0.040 \\
\hline \multicolumn{2}{|c|}{ UF } & 33.9 & 33.7 & 0.097 & 0.055 \\
\hline \multicolumn{2}{|c|}{ CV (\%) } & 10.0 & 31.1 & 17.5 & 29.8 \\
\hline \multicolumn{2}{|c|}{ LSD at $5 \%$ for $S S \times F S$} & NS & NS & 0.015 & NS \\
\hline Seed treatment & Foliar spray & & & & \\
\hline \multirow[t]{3}{*}{ MST } & CFS10 & 20.0 & 21.9 & 0.101 & 0.042 \\
\hline & CFS20 & 22.5 & 20.8 & 0.091 & 0.047 \\
\hline & UF & 25.7 & 25.3 & 0.084 & 0.045 \\
\hline \multirow[t]{3}{*}{ CST } & CFS10 & 23.4 & 25.1 & 0.086 & 0.043 \\
\hline & CFS20 & 21.5 & 21.4 & 0.093 & 0.053 \\
\hline & UF & 23.4 & 25.9 & 0.031 & 0.044 \\
\hline \multirow[t]{2}{*}{ US } & CFS10 & 27.5 & 23.8 & 0.063 & 0.044 \\
\hline & CFS20 & 28.4 & 20.9 & 0.066 & 0.051 \\
\hline \multicolumn{2}{|c|}{ UF } & 42.7 & 27.0 & 0.110 & 0.052 \\
\hline \multicolumn{2}{|c|}{ CV (\%) } & 8.1 & 7.1 & 23.7 & 29.2 \\
\hline \multicolumn{2}{|c|}{ LSD at $5 \%$ for ST $\times$ FS } & 2.8 & 1.3 & 0.028 & NS \\
\hline
\end{tabular}

MST=Mancozeb seed treatment; CST=Carbendazim seed treatment; CFS10 and $20=$ Carbendazim foliar spray at 10 and 20 days interval; UF=Unsprayed foliar; US=Untreated seed; LSD=Least significant difference; NS=Non significant difference; $F S=F o l i a r$ spray; $S S=S o i l$ solarization

Table 5: Effect of solarization $x$ seed treatment, soil solarization $x$ foliar sprays and seed treatment $x$ foliar sprays interactions on area under disease progress curve (AUDPC) and Disease progress rate of bean anthracnose during 2010 main cropping season.

6.7 and 7.8, respectively as compared to 16.3 in the control (Table 4). At Hirna, the combination of solarized soil with carbendazim foliar sprays frequencies at 10 and 20 intervals showed infected pods per plant of 3.6 and 3.9, respectively over the control (5.9).

\section{Area under disease progress curve and disease progress rate}

Interaction between soil solarization $\mathrm{x}$ seed treatments was highly significant $(P<0.01)$ in reducing AUDPC at Haramaya and non significant at Hirna. Where, the combination of non-solarized soil with mancozeb and carbendazim seed treatments showed AUDPC of 24.3\%days and $24.7 \%$-days, respectively over the control (36.6\%-days). And combination of solarized soil with the same fungicides seed treatments showed lower AUDPC of 21.1\%-days and 20.8\%-days, respectively over the control (Table 5).

Significant interaction $(P<0.01)$ between the levels of seed treatments and foliar sprays were observed at Haramaya and Hirna.
At Haramaya, lower AUDPC was calculated from the interaction of mancozeb seed treatment with carbendazim spray frequencies at 10 and 20 days intervals of $20 \%$-days and $22.5 \%$-days, respectively than the control (42.7\%-days). At Hirna, maximum AUDPC was obtained from untreated plots (27\%-days). While, lower AUDPC was calculated from the combination of mancozeb seed treatment with carbendazim foliar spray frequency at 10 days intervals, and combinations of carbendazim seed treatment with the same fungicide foliar spray frequency at 10 days intervals. Generally, variation in anthracnose of common bean area under disease progress curve due to levels of solarization and fungicide seed treatments and foliar sprays were clearly observed and AUDPC was higher in non-solarized soil than solarized soil both at Haramaya and Hirna (Table 5). AUDPC was lower in plots treated with combination of mancozeb seed treatment and carbendazim foliar spray frequencies at 10 day intervals than other seed and foliar treated fungicides. There were no significant interaction between levels of solarization and foliar sprays in reducing AUDPC at Hirna and Haramaya.

Disease progress rate helps to determine whether disease develops in one treatment faster than the other [30]. Interaction effects of soil solarization $\mathrm{x}$ seed treatment, soil solarization $\mathrm{x}$ foliar sprays, seed treatment $\mathrm{x}$ foliar sprays were significant on progress rate at Haramaya and non significant at Hirna (Table 5). The lowest progress rate was calculated from combination of carbendazim seed treatment with unsprayed foliar $(0.031 \%$-days $)$ while, the highest progress rate was obtained from the control (0.110\%-days). Generally, variation in bean anthracnose disease progress rate due to solarization, fungicides seed treatment and foliar sprays were clearly observed and rate of disease progress was higher at Haramaya than Hirna.

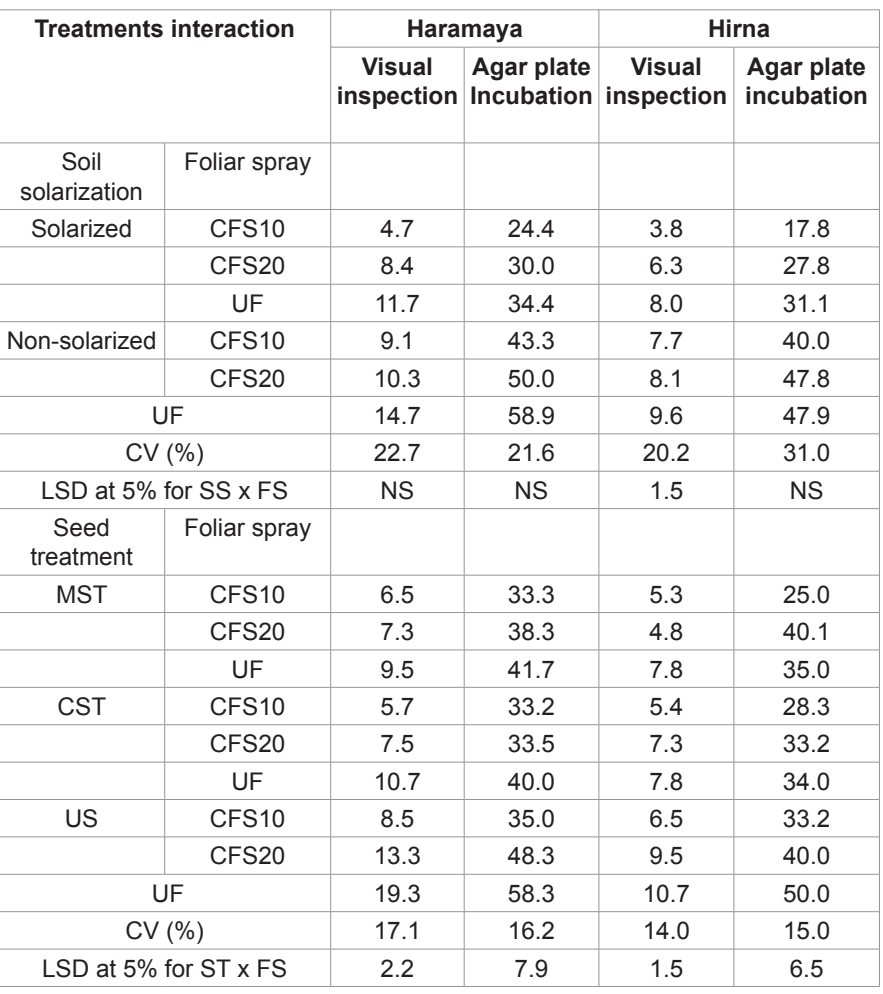

MST=Mancozeb seed treatment; CST=Carbendazim seed treatment; CFS10 and $20=$ Carbendazim foliar spray at 10 and 20 days interval; UF=Unsprayed foliar; US=Untreated seed; LSD=Least significant difference; NS=Non significant difference; SS=Soil solarization; FS=Foliar sprays

Table 6: Effect of soil solarization $\mathrm{x}$ foliar sprays, seed treatment $\mathrm{x}$ foliar spray interactions on anthracnose infection (\%) of bean seed at Haramaya and Hirna during 2010 main cropping season. 
Citation: Mohammed A, Ayalew A, Dechassa N (2013) Effect of Integrated Management of Bean Anthracnose (Colletotrichum lindemuthianum Sacc. and Magn.) Through Soil Solarization and Fungicide Applications on Epidemics of the Disease and Seed Health in Hararghe Highlands, Ethiopia. J Plant Pathol Microb 4: 182 doi:10.4172/2157-7471.1000182

\section{Effect of soil solarization and fungicide applications on seed health}

Infected seeds played considerable role in the establishment of economically important plant disease in the field resulting in the heavy reduction of crop yield and infected seeds also have lower seed quality leading to reduced market values, poor germination and field establishment [31]. Apart from this, infected seeds act as vehicle in carrying pathogens to uninfected areas within a country and from one country to the other. Interaction effects of soil solarization $\mathrm{x}$ seed treatment, solarization $\mathrm{x}$ foliar spray and solarization $\mathrm{x}$ seed treatment $\mathrm{x}$ foliar spray, no significant difference was observed in reducing seed infection both in visual inspection and agar plate incubation at both locations except combinations of soil solarization $\mathrm{x}$ foliar sprays at Hirna for visible infection of seed; the same was true for seed treatment $\mathrm{x}$ foliar sprays $(P<0.01)$ in both methods of seed health detection at each location (Table 6). Combination of solarized soil with carbendazim spray frequencies at 10 day intervals reduced visible seed infection by $60 \%$. The combination of non-solarized soil with carbendazim spray frequencies at 10 day intervals reduced visible seed infection by $19 \%$ at Hirna (Table 6). The interaction of mancozeb seed treatment with carbendazim spray frequencies at 10 and 20 intervals reduced percentages of seed infection on agar plate incubation of seed infection by $42.8 \%$ and $34.3 \%$, respectively over the control at Haramaya. Similarly, the combination of carbendazim seed treatment with the same fungicide spray frequencies at 10 and 20 days intervals reduced seed infection on agar plate incubation by $43.4 \%$ and $33.6 \%$, respectively over the control at Hirna (Table 6). The relationships were evident between infection levels in the pods and seed infection, as determined by seedling grow-out in laboratory tests reported by Vechiato et al. [32]. These results are in line with those reported by Ravi et al. [33] in that agar plate incubation was found to be the best and yielded maximum percentage of seed infection. The percentage of infected seed is an important determines factor and indicates virulence of the pathogen during the growing season since the secondary inoculum produced will be proportional to the amount of initial inoculum [34]. Based on detection of seed-borne fungi using agar plate method, C. lindemuthianum was found to be the most important seed-borne pathogen and is found in high frequency with severe crop damage followed by Phaeoisariopsis griseola, and Ascochyta phaseolorum in many bean growing areas of Ethiopia [35].

\section{Conclusions}

In the Hararghe highlands, bean anthracnose is an important disease that calls for better attention, for economical management using combinations of soil solarization, fungicide seed treatments with foliar sprays. Differences in epidemics occurred within each level of solarization due to fungicide applications under natural infection. Plots treated with combinations of mancozeb seed treatment and carbendazim spray frequencies at 10 days' intervals obtained the best protection in terms of disease severity, infected pods per plant AUDPC. Therefore, this study contributes to integrated bean anthracnose management options using soil solarization seed treatment and foliar spray. Bean growers should be encouraged to use seed treatment and other cultural practices applicable in these areas against anthracnose when growing susceptible bean cultivars, and the use of resistant varieties and producing pathogen free seeds would be a cheap means of controlling the anthracnose disease and need to be explored.

\section{Acknowledgement}

Authors are grateful to Haimanot Bizuneh for her assistance in laboratory work and Abdujebbar Mohammed for moral support. Financial support was provided by ministry of education.

\section{References}

1. Food and Agriculture Organization (2005) Crop production statistics data (Accessed October 30 2009).

2. Popelka JC, Terryn N, Higgins TJV (2004) Gene technology for grain legumes: Can it contribute to the food challenge in developing countries? Plant Science 167: 195-206

3. Wortman C, Kirkby RA, Eledu CA, Allen DJ (1998) Atlas of common bean (Phaseolus vulgaris L.) production in Africa (CIAT Publication No. 297). Cali, Colombia: International Center for Tropical Agriculture.

4. Habtu A (1994) Epidemiology of bean rust in Ethiopia, Ph.D Thesis. The Netherlands: Journal of Pest Management 47: 211-219.

5. Habtu A, Sache I, Zadoks JC (1996) A survey of cropping practices and folia diseases II. Severity-damage relationship. Pest Management Journal of Ethiopia 2: 113.

6. Habtu A (1987) Haricot bean diseases and their importance. Ethiopian Journal of Agricultural Sciences 9: 55-66.

7. Schwartz RF, Pastor-Corrales MA, Singh SP (1983) New sources of resistance to anthracnose and angular leaf spot of bean (Phaseolus vulgaris L.). Euphytica 31: $741-754$

8. Pastor-Corrales MA, Tu JC (1989) Anthracnose. Bean production problems in the Tropics. (2ndedn), CIAT, Cali, USA.

9. Pelaso MJ (1992) Bean anthracnose in the State of Minas Gerais, Brazil, 86108

10. Hall R (1994) Compendium of bean diseases. (2ndedn), APS Press, the American Phytopathological Society, St. Paul, USA.

11. Feraz, S (1980) Angular leaf spot. Bean production problems: disease, insects, soil and climatic constraints of Phaseolus vulgaris, International Centre for Tropical Agriculture (CIAT) Cali, USA, 55p-65p.

12. Freeman S, Nizani Y, Dotan S, Even S, Sando T (1997) Control of Colletotrichum acutatum in Strawberry Under Laboratory, Greenhouse, and Field Conditions. Plant Disease 81: 749-752

13. Koch SH (1996) Colletotrichum spp. On dry bean and lupines in South Africa. University of Pretoria, Pretoria.

14. Barbercheck ME, Von Broembsen SL (1986) Effects of soil solarization on plant-parasitic nematodes and Phytophthora cinnamomi in South Africa. Plant Disease 70: 945-950.

15. Beshir T (1997) Loss assessment study on haricot bean due to anthracnose. Pest Management Journal of Ethiopia 1: 67-72.

16. CIAT (1988) Inform annual 1988: bean program. Working Paper 72. CIAT, CIAT African Workshop Series, Colombia.

17. CIAT (1987) Anthracnose. Standard system for the evaluation of bean germplasm in CIAT, CIAT, Coli, Colombia. The genera of fungi. Hafner, New York. 496 PP. Colombia. Common bacterial blight in Phaseolus bean. Plant Pathology 45: 1126-1133.

18. Wheeler JBEJ (1969) An Introduction to Plant Diseases. Wiley, London, UK

19. Amare A (2009) Disease diagnosis and techniques in plant pathology, teaching material, School of Plant Sciences, Haramaya University, Haramaya/Ethiopia.

20. Campbell CL, Madden LV (1990) Introduction to Plant Disease Epidemiology. John Wiley and Sons, USA.

21. SAS (Statistical Analysis System) software (2009) Version 9.2. Inc. Carry, North California, USA.

22. GenStat (2009) GenStat Release 12.1. PC/windows XP/ $12^{\text {th }}$ edition 06 January. Copy right 2009 VSN International. Ltd.

23. Dillard HR, Cobb AC (1993) Survival of Colletotrichum lindemuthianum in bean debris in New York State. Plant Disease 77: 1233-1238.

24. Fininsa C, Tefera T (2002) Effect of primarily inoculum source of bean anthracnose and their effect on epidemics and yield. Tropical Science 42: 3034.

25. Sindhan GS, Bose SK (1981) Evaluation of fungicides against anthracnose of 
Citation: Mohammed A, Ayalew A, Dechassa N (2013) Effect of Integrated Management of Bean Anthracnose (Colletotrichum lindemuthianum Sacc. and Magn.) Through Soil Solarization and Fungicide Applications on Epidemics of the Disease and Seed Health in Hararghe Highlands, Ethiopia. J Plant Pathol Microb 4: 182 doi:10.4172/2157-7471.1000182

French bean caused by Colletotrichum lindemuthianum. Indian Phytopathology 34: $325-329$

26. Gwary DM, Bwatanglang N, Bdliya BS (2008) Integrated Management of Sorghum Anthracnose Through the Use of Fungicides, Crop Varieties and Manipulation of Sowing Dates in Sudan Savanna of Nigeria. International Journal of Agriculture and Biology 10: 661-664.

27. Chakraborty MR, Chatterjee NC, Quimio TH (2008) Integrated management of fusarial wilt of egg plant (Solanum melongena) with soil solarization. Micologia Aplicada International 21: 25-36.

28. Jenny Davidson (2010) Pulse seed treatments and foliar fungicides. (7thedn), South Australian Research and Development Institute, (08) 8303 9389; Kurt Lindbeck, Industry and Investment New South Wales.

29. Pastor-Corrales MA, Otoya MM, Molina A, Singh SP (1995) Resistance to Colletotrichum lindemuthianum isolates from Middle and Andead South America in different common bean race. Plant Disease 79: 63-67.
30. Jones DG (1998) The Epidemiology of Plant Diseases. Kluwer Academic Publishers, UK.

31. Neergaard P (1979) Seed pathology. Revised edition, Vol. I and II. The Macmillan Press Ltd

32. Vechiato MH, Castro JL, Ishimura I, Sabino JC, Menten JOM (1997) Bean anthracnose: relationship between pod severity and the incidence of the pathogen in the seed. Brazilian Phytopathological 22: 159-163.

33. Ravi S, Sabitha D, Valluvaparidasan V, Jeyalakshmi C (1999) Impact of seed-borne Colletotrichum lindemuthianum on french bean seed quality. Acta Phytopathologica ET Entomologica Hungarica 34: 283-291.

34. Tu JC (1983) Epidemiology of anthracnose caused by Colletotrichum lindemuthianum on white bean (Phaseolus vulgaris) in Southern Ontario: Survival of the pathogen. Plant Disease 67: 402-404.

35. Mohammed Y, Sangchote S (2005) Occurrence and distribution of major seedborne fungi associated with Phaseolus bean seed in Ethiopia. Kasetsart J, Nat Sci 39: 216-225 